\title{
A Morphometric Study of Foramen Ovale
}

\author{
Foramen Ovalenin Morfometrik Bir Arașturması
}

M.S. SOMESH ${ }^{1}$, H.B. SRIDEVI ${ }^{2}$, Latha V. PRABHU ${ }^{3}$, M.S. Gangadhara SWAMY ${ }^{3}$, Ashwin KRISHNAMURTHY', B.V.MURLIMANJU' ${ }^{3}$ Ganesh Kumar CHETTIAR ${ }^{3}$

${ }^{1}$ Srinivas Institute of Medical Sciences and Research Centre, Mukka, Mangalore, India

${ }^{2}$ Kasturba Medical College, Manipal University,Department of Pathology, Mangalore, India

${ }^{3}$ Kasturba Medical College, Manipal University, Department of Anatomy, Mangalore, India

Correspondence address: M.S.SOMESH / E-mail: drsomeshms@gmail.com

\section{ABSTRACT}

AIM: To note the morphological variations and morphometric details of foramina ovale in dry adult skulls of Indian origin.

MATERIAL and METHODS: 82 dry adult human skulls of unknown sex and of Indian origin were obtained and variations in appearance and number of foramen ovale were noted. The length and width of the foramina ovale of both sides were determined using digital Vernier calipers and area (A) was also calculated and analyzed.

RESULTS: Out of 82 adult skulls, the values for the right side was $7.64 \pm 1.194 \mathrm{~mm}, 5.128 \pm 0.827 \mathrm{~mm}$ and $30.808 \pm 7.545 \mathrm{~mm} 2$ and for the left side the values was $7.561 \pm 1.123 \mathrm{~mm}, 5.244 \pm 0.950 \mathrm{~mm}$ and $31.310 \pm 8.262 \mathrm{~mm} 2$ respectively, for the mean length, width and area of the foramen ovale. The shape of foramen was typically ovale in most of the skulls (56.70\%) with some bony variations such as spine, tubercles etc.

CONCLUSION: There was no statistically significant difference between the two sides in length, width and area of foramen ovale and there was a positive correlation between lengths and areas of both sides.

KEYWORDS: Foramen ovale, Morphology, Morphometry, Skull, Sphenoid

öz

AMAÇ: Hint kökenli erişkin kafataslarında foramen ovalenin morfolojik varyasyonları ve morfometrik detaylarının vurgulanması.

YÖNTEM ve GEREÇ: Hint kökenli, cinsiyeti bilinmeyen 82 adet kuru erişkin insan kafatası elde edilerek foramen ovalelerinin görünümleri ve varyasyonları incelendi. Her iki taraftaki foramen ovalelerin uzunluk ve genişlikleri Vernier pergelleri ile belirlendi ve alanları hesaplanarak analiz edildi.

BULGULAR: 82 erişkin kafatasında foramen ovalenin sırasıyla ortalama uzunluk, genişlik ve alanı sağ tarafta $7.64 \pm 1.194 \mathrm{~mm}, 5.128 \pm 0.827$ $\mathrm{mm}$ ve $30.808 \pm 7.545 \mathrm{~mm} 2$, sol tarafta ise $7.561 \pm 1.123 \mathrm{~mm}, 5.244 \pm 0.950 \mathrm{~mm}$ ve $31.310 \pm 8.262 \mathrm{~mm} 2$ olarak saptandı. Çoğu kafatasında foramenin şekli tipik olarak oval $(\% 56,70)$ olmakla birlikte bazı spinöz, tüberküler vs. kemik varyasyonları da mevcuttu.

SONUÇ: Her iki tarafta foramen ovalenin uzunluk, genişlik ve alanı açısından istatistiksel olarak anlamlı fark bulunmadığı ve her iki tarafın uzunluk ve alanları arasında pozitif korelasyon olduğu gözlendi.

ANAHTAR SÖZCÜKLER: Foramen ovale, Morfoloji, Morfometri, Kafatası, Sfenoid

\section{INTRODUCTION}

The cerebral surface of each greater wing of sphenoid bone forms part of the middle cranial fossa of the skull containing numerous foramina and fissures, which accommodate several vessels and nerves.

Foramen ovale (FO) is located in the posterior part of the greater wing for the transmission of the mandibular nerve, the accessory meningeal artery, lesser petrosal nerve and an emissary vein. This FO is normally located in the greater wing of the sphenoid bone, posterior and lateral to the foramen rotundum $(17,20)$ and it opens into the infratemporal fossa through its other opening on the lateral surface of greater wing (19).
There are some studies which indicates the abnormal morphology of the FO, such that it can be occasionally covered by ossified ligaments stretching between the lateral pterygoid process and the sphenoid spine $(4,11)$ or its venous part may be compartmentalised by a bony spur located antero-medially resulting in doubled FO (15). Another study conducted has found FO to be divided into 2 or 3 components in $4.5 \%$ of the 100 macerated skulls studied with some irregularities (17).

Regarding the developmental aspects of foramen ovale, it is situated at the posterior border of greater wing of sphenoid. This sphenoid bone has both intramembranous and endochondral ossification centers and it consists of the body (basisphenoid), the paired lesser wings (orbitosphenoids), 
and the greater wings (alisphenoids). The basisphenoid is derived mainly from presphenoid and postsphenoid centres and the postsphenoid centre is the one which is associated with the development of the greater wing of sphenoid. The first ossification centre appears for alisphenoids and its large portion forms the greater wing of sphenoid by membranous ossification. The mandibular nerve becomes surrounded by cartilage to form the foramen ovale. At 22 weeks (7th foetal month), the foramen ovale can be seen as discrete ringshaped opening in the area of unossified cartilage that can be well recognised 3 years after birth at the latest (22). The mean length of the foramen ovale is about $3.85 \mathrm{~mm}$ in the newborn and about $7.2 \mathrm{~mm}$ in adults and its width extends from 1.81 $\mathrm{mm}$ in the newborn to $3.7 \mathrm{~mm}$ in case of adults (14).

FO is an important constituent of cranial anatomy with high significance in neurosurgery as it enables access to the trigeminal nerve. Thus knowledge of its position is clinically important in the event of anaesthesia of the mandibular nerve as well as in cases of assessment of skull base asymmetries where these foramina measurements become important (8).

As the information regarding the morphometry of the FO in humans is very limited in the literature, this study was done to present the morphological variants and morphometric details of the FO in adult human skulls of Indian origin and also to compare these details with those of previous studies of other ethnic origin.

\section{MATERIAL and METHODS}

The materials for the present study included eighty two (82) dry adult, Indian human skulls of unknown sex and origin were obtained from Bone Bank of the Department of Anatomy, Kasturba Medical College, Mangalore \& Manipal, Manipal University, Karnataka State, India. The posterior part of greater wing of sphenoid was carefully examined for the existence of FO and its patency was confirmed by inserting a probe through each. Skulls in poor conditions or skulls with partly damaged surroundings of the FO were not considered.

The antero-posterior diameter (length) or" L"and perpendicular to this, transverse diameter (width) or "W" of the foramina ovale of both sides are determined using Digital Vernier calipers with a precision of $0.1 \mathrm{~mm}$ (16). Each dimension was measured thrice and the mean figure recorded. The data collected was checked for errors prior to analysis. From these obtained values, area " $A$ " of the foramina ovale was calculated using the formula: $(\pi \times L \times B) / 4$ or $[(3.142 \times L \times B) / 4](5)$.

Data analysis of the obtained values was performed statistically using SPSS software version 11.5 for Windows. The mean and standard deviation (SD) of each dimension was computed. Right and left differences were analysed. A comparison was made of the means of the dimensions using Student's t-test. The relation between continuous variables was investigated by means of Pearson's correlation coefficient ( $r$ ). A probability (p) of less than 0.05 was considered statistically significant.

\section{RESULTS}

\section{a. Morphology}

FO is normally located in the greater wing of the sphenoid bone, posterior and lateral to the foramen rotundum and the present study was conducted on a total of 164 sides in 82 dry adult skulls. Various shapes of the FO were observed, of which it was typically oval in 93 sides (Figure 1, arrow; Table I; 48 right, 45 left), almond shape in 47 sides (Figure 1, arrowhead; Table II; 24 right, 23 left), typically round in 18 sides (Figure 2, arrowhead; Table l; 8 right, 10 left ) and irregular shaped in 6 sides (Figure 3 arrowhead; Table l; 2 right, 4 left). Oval shaped FO was observed in 25 sides bilaterally, whereas bilateral almond was observed in 12 sides and the incidence of oval, almond, round and irregular shaped FO observed in our study were $56.70 \%, 28.65 \%, 10.97 \%$ and $3.65 \%$ respectively (Table I).

In 7 sides ( 2 left, 5 right), the base of skull had spine on the margin of FO (Figure 2, arrow), and 5 sides (2 left, 3 right) had tubercle protruding from margin (Figure 3, arrowhead). Also a bony lamina extending from lateral pterygoid plate dividing the foramen into two incomplete compartments, a larger medial and smaller lateral compartment was seen in 2 skulls, which was unilateral in 1 case (Figure 3, arrows) and bilateral in another skull (Figure 4A,B, black \& red arrowheads).

\section{b. Morphometry}

In the present study, the mean length of FO was $7.64 \pm 1.194$ $\mathrm{mm}$ on right side and $7.561 \pm 1.123 \mathrm{~mm}$ on left side (Table II; Figure 5A), whereas the observed maximum and minimum length was $11.0 \mathrm{~mm}, 5.0 \mathrm{~mm}$ and $11.0 \mathrm{~mm}, 4.5 \mathrm{~mm}$ on right and left sides respectively (Table II). However, the difference between the length of right and left side, was not statistically significant (Table III). The Maximum width of FO was $7.5 \mathrm{~mm}$ on right and $8.0 \mathrm{~mm}$ on left side, while the minimum width was $3.0 \mathrm{~mm}$ on both sides (Table II), and the mean width on right side was $5.128 \pm 0.827 \mathrm{~mm}$ and $5.244 \pm 0.950 \mathrm{~mm}$ on left side (Table II; Figure $5 \mathrm{~A}$ ) with no significant difference between the sides (Table III). When the mean area (A) of FO

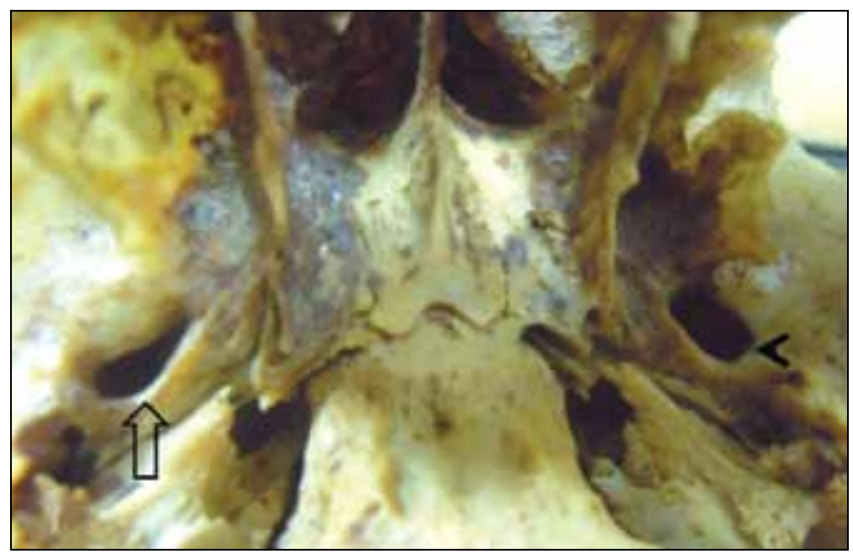

Figure 1: Base of skull with arrow showing Almond Shaped Foramen Ovale on right side; arrow head pointing Oval Foramen Ovale on left. 


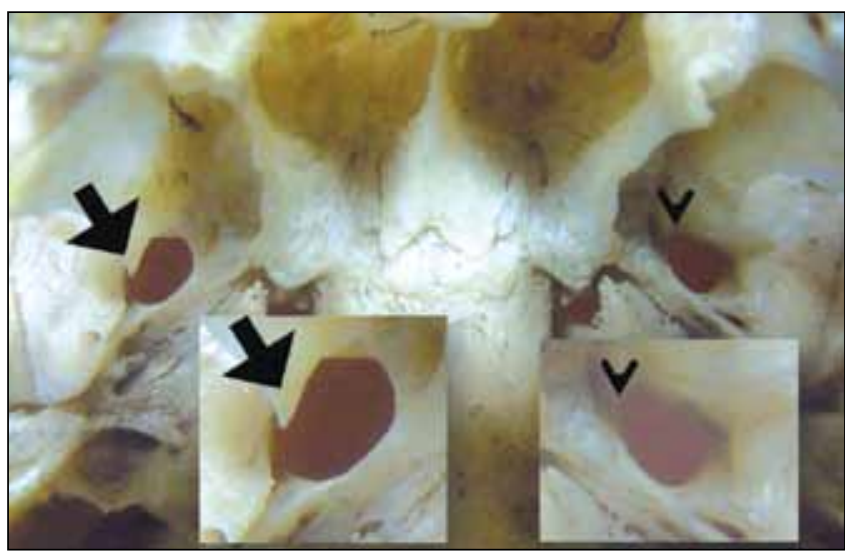

Figure 2: Base of skull showing right foramen ovale with spine (arrow) on its anterior margin and round shaped left foramen ovale shows presence of tubercle (arrow head).

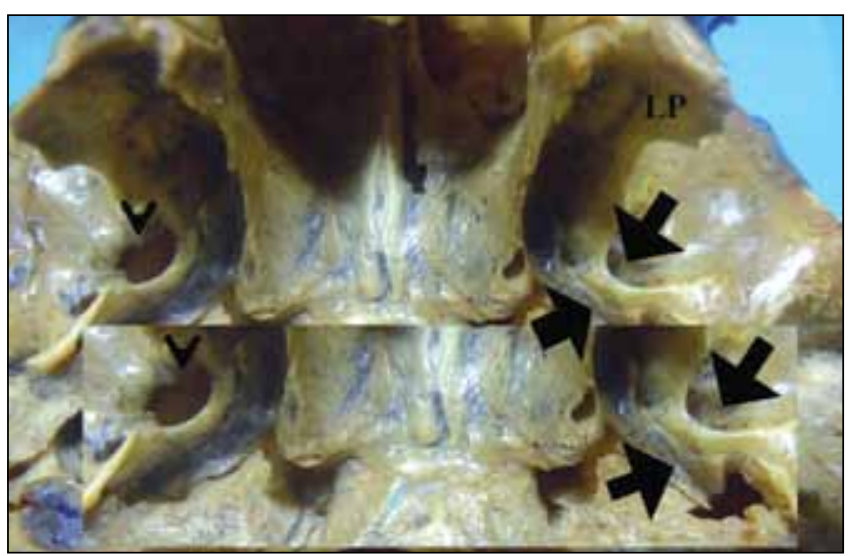

Figure 3: Base of skull showing right foramen ovale with a raised tubercle leading to an Irregular shape foramen ovale (arrow head); Bony lamina extending from Lateral Pterygoid plate (LP) and divide the left foramen ovale into two compartments (arrows).

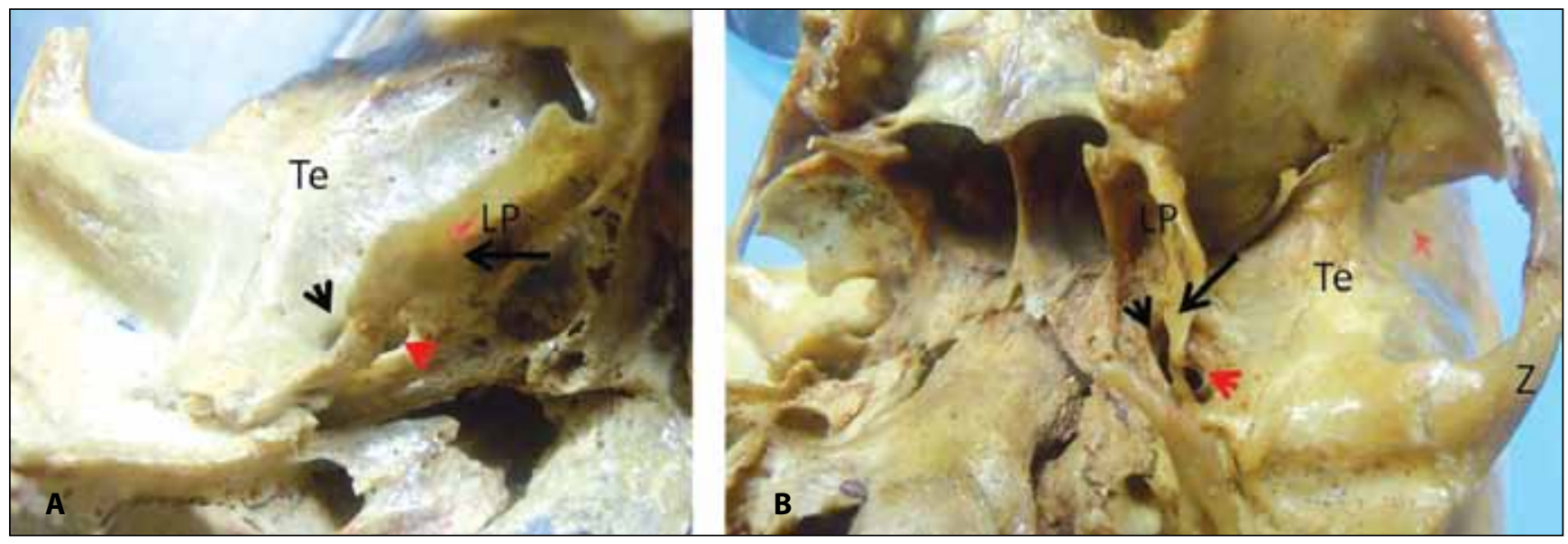

Figure 4: A) Base of skull with bony lamina extending from Lateral Pterygoid plate (LP) over the right foramen ovale (arrow) and dividing into two incomplete compartments (Red arrow head - Medial; black arrow head - Lateral). Te - temporal bone; LP - lateral pterygoid. B) Base of same skull showing the bony lamina extending from Lateral Pterygoid plate (LP) over the left foramen ovale (Arrow) and dividing into two incomplete compartments (Red arrow head - Medial; Black arrow head - Lateral). Te - temporal bone; LP - lateral pterygoid; $\mathbf{Z}=$ zygomatic bone.

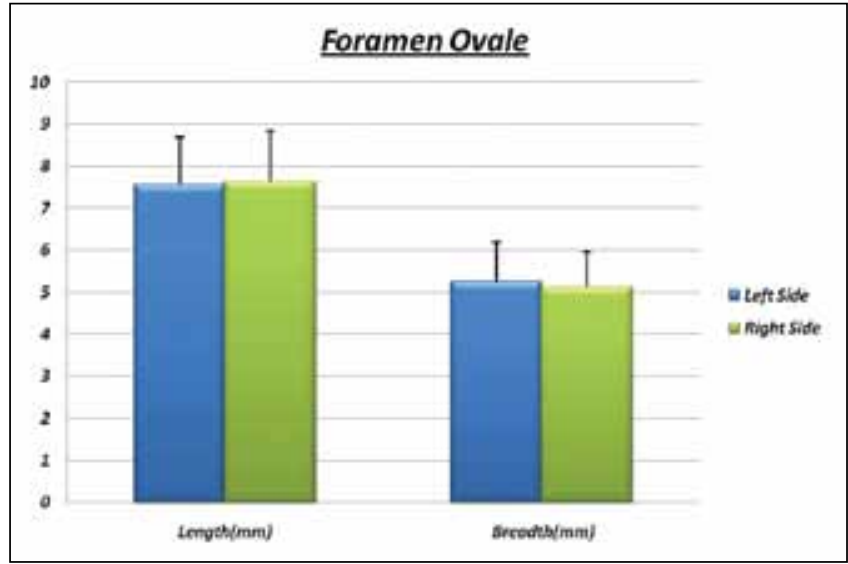

Figure 5A: Bar diagram showing Length $\{(\mathrm{L})$ (in $\mathrm{mm}$ )\}, Breadth $\{(B)$ (in $\mathrm{mm}$ ) $\}$ of Foramen Ovale on both sides of skull. The values are expressed as Mean \pm SD.

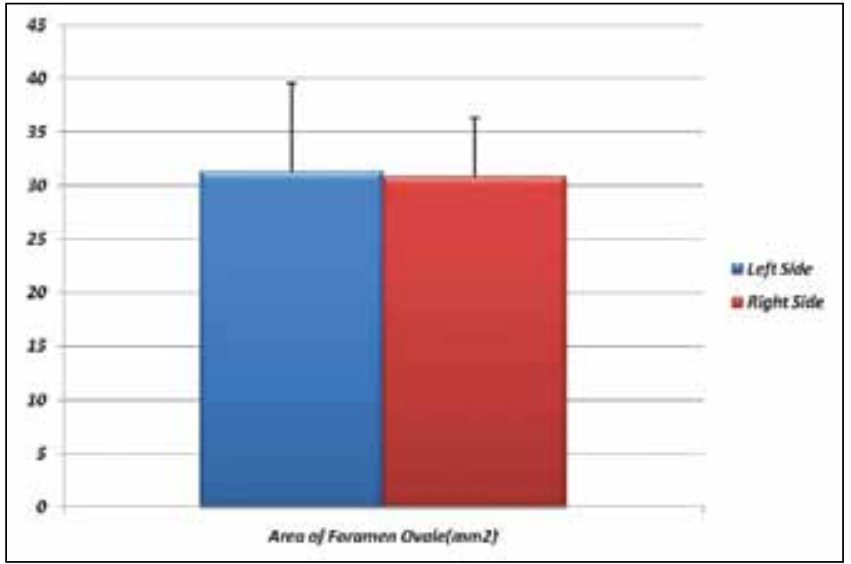

Figure 5B: Bar diagram showing area $\left\{(\mathrm{A})\right.$ (in $\left.\left.\mathrm{mm}^{2}\right)\right\}$ of Foramen Ovale on both sides of skull. The values are expressed as Mean \pm SD. 
Table I: Variations in Appearance of Foramen Ovale

\begin{tabular}{|c|c|c|c|}
\hline Shape & Right ( $n=82$ ) & Left $(n=82)$ & Total $(n=164)$ \\
\hline Oval & 48 (58.53\%) & 45 (54.87\%) & 93 (56.70\%) \\
\hline Almond & 24 (29.26\%) & $23(28.04 \%)$ & 47 (28.65\%) \\
\hline Round & 08 (9.75\%) & $10(12.19 \%)$ & $18(10.97 \%)$ \\
\hline Irregular & $02(2.43 \%)$ & 04 (4.87\%) & $06(3.65 \%)$ \\
\hline
\end{tabular}

Table II: The Foramen Ovale Dimensions

\begin{tabular}{|c|c|c|c|c|c|c|c|}
\hline & & LTL & RTL & LTB & RTB & LTA & RTA \\
\hline Mean & & 7.561 & 7.640 & 5.244 & 5.128 & 31.310 & 30.808 \\
\hline SD & & 1.123 & 1.194 & 0.950 & 0.827 & 8.262 & 7.545 \\
\hline Minimum & & 4.5 & 5.0 & 3.0 & 3.0 & 14.13 & 14.13 \\
\hline Maximum & & 11.0 & 11.0 & 8.0 & 7.5 & 53.38 & 54.95 \\
\hline \multirow[t]{5}{*}{ Percentiles } & 3 & 4.745 & 5.490 & 4.000 & 4.000 & 15.860 & 17.238 \\
\hline & 25 & 7.000 & 6.875 & 4.500 & 4.500 & 25.512 & 25.021 \\
\hline & 50 & 8.000 & 8.000 & 5.000 & 5.000 & 30.811 & 31.400 \\
\hline & 75 & 8.500 & 8.500 & 6.000 & 5.625 & 37.680 & 35.423 \\
\hline & 97 & 9.255 & 10.000 & 7.500 & 7.000 & 50.043 & 48.301 \\
\hline
\end{tabular}

LTL - left length, RTL - right length, LTB - left breadth, $\mathbf{R}$ TB - right breadth, LTA - left area, $\mathbf{R T A}$ - right area, SD - standard deviation, all measurements in mm.

Table III: Mean, Standard Deviations (SD), t and P Values for Foramen Ovale Parameters - Side Comparative Results

\begin{tabular}{l|c|c|c|c|}
\multirow{2}{*}{ Parameters } & Left Side $(\mathbf{N}=\mathbf{8 2})$ & Right Side $(\mathbf{N}=\mathbf{8 2})$ & $\mathbf{t}$ & $\mathbf{p}$ \\
\cline { 2 - 5 } Length $\{(\mathrm{L})$ in $\mathrm{mm}\}$ & Mean \pm SD & Mean \pm SD $(\mathbf{m m})$ & 0.438 & 0.662 \\
Breadth $\{(\mathrm{B})$ in $\mathrm{mm}\}$ & $7.561 \pm 1.123$ & $7.640 \pm 1.194$ & 0.833 & 0.406 \\
\hline Area $\left\{(\mathrm{A})\right.$ in $\left.\mathrm{mm}^{2}\right\}$ & $5.244 \pm 0.950$ & $5.128 \pm 0.827$ & 0.406 & 0.685
\end{tabular}

$P \leq 0.05$ is considered a significant value.

Table IV: The Pearson Correlation Coefficient ( $r$ ) and $p$-Value of the Continuous Variables

\begin{tabular}{|c|c|c|c|c|c|c|c|}
\hline & & LTL & LTB & LTA & RTL & RTB & RTA \\
\hline \multirow{2}{*}{ LTL } & $r$ & - & .301 & .730 & .610 & .350 & .574 \\
\hline & $p$ & - & .006 & .000 & .000 & .001 & .000 \\
\hline \multirow{2}{*}{ LTB } & $r$ & .301 & - & .865 & .217 & .404 & .382 \\
\hline & $p$ & .006 & - & .000 & .050 & .000 & .000 \\
\hline \multirow{2}{*}{ LTA } & $r$ & .730 & .865 & - & .462 & .454 & .556 \\
\hline & $p$ & .000 & .000 & - & .000 & .000 & .000 \\
\hline \multirow{2}{*}{ RTL } & $r$ & 610 & .217 & .462 & - & .225 & .752 \\
\hline & $p$ & .000 & .050 & .000 & - & .042 & .000 \\
\hline \multirow{2}{*}{ RTB } & $r$ & .350 & .404 & .454 & .225 & - & .801 \\
\hline & $p$ & .001 & .000 & .000 & .042 & - & .000 \\
\hline \multirow{2}{*}{ RTA } & $r$ & .574 & .382 & .556 & .752 & .801 & - \\
\hline & $p$ & .000 & .000 & .000 & .000 & .000 & - \\
\hline
\end{tabular}

LTL - left length, LTB - left breadth, LTA - left area, $\mathbf{R T L}$ - right length, $\mathbf{R T B}$ - right breadth, $\mathbf{R T A}$ - right area, $\boldsymbol{r}$ - Pearson correlation coefficient; $p \leq 0.05$ is significant 
was calculated, based on the formula obtained by previous studies, it was $30.808 \pm 7.545 \mathrm{~mm}^{2}\left(54.95-14.13 \mathrm{~mm}^{2}\right)$ on the right side and $31.310 \pm 8.262 \mathrm{~mm}^{2}\left(53.38-14.13 \mathrm{~mm}^{2}\right)$ on the left side (Table II; Figure 5B), with no statistically significant difference between the two sides (Table III). There was a positive correlation between lengths and areas on both sides, but no correlation was found between length and width on each side of the FO (Table IV).

\section{DISCUSSION}

Information on foramina variants of the human skull gives insight into associations between neurovascular anatomy and the cranial morphology. The sphenoid bone, because of its complex structure and intricate embryological origin, should be studied in different anatomical aspects, including its normal and abnormal variation.

FO is used for various invasive surgical as well as diagnostic procedures such as electroencephalographic analysis of the seizure for patients undergoing selective amygdalohippocampectomy (21), microvascular decompression by percutaneous trigeminal rhizotomy for trigeminal neuralgia $(7,9)$ and percutaneous biopsy of cavernous sinus tumours (18) etc. The technique of CT-guided transfacial fine needle aspiration technique through the $\mathrm{FO}$ is used to diagnose squamous cell carcinoma, meningioma, meckel etc., and allows biopsy of deep lesions that would otherwise require open surgical biopsy or craniotomy $(6,2)$, thus helping to decrease patient morbidity and significantly decrease the cost involved.

In our study, the maximal length of $\mathrm{FO}$ was $11 \mathrm{~mm}$ and its minimal length was $4.5 \mathrm{~mm}$ whereas these values in previous studies like Arun (1) and Osunwoke et al. (16) were $(9.8 \mathrm{~mm}$ and $2.9 \mathrm{~mm}$ ) and $(9.5 \mathrm{~mm}$ and $5.0 \mathrm{~mm}$ ) respectively. Also the mean length of FO in our study was $7.64 \pm 1.194 \mathrm{~mm}$ on the right and $7.561 \pm 1.123 \mathrm{~mm}$ on the left side and this difference was not significant even though the right FO was slightly longer than left. Similarly in various other studies, the mean length of FO was $7.48 \mathrm{~mm}(22) ; 7.46 \pm 1.41 \mathrm{~mm}$ on right and $7.01 \pm 1.41 \mathrm{~mm}$ on left sides (3) and similar to the present work, there was no significant difference between right and left sides. Also, according to Lang et al., (14), the mean length of FO is $7.2 \mathrm{~mm}$, whereas in a fluoroscopically-assisted laser targeting of the FO, as conducted in New York, it was $6.9 \mathrm{~mm}$ on right side and $6.8 \mathrm{~mm}$ on left, less than the present values (13).

In this study, the maximum width of FO was $7.5 \mathrm{~mm}$ on right and $8.0 \mathrm{~mm}$ on left side, while its minimum width was 3.0 $\mathrm{mm}$ on both sides. Also the mean width on right side was $5.128 \pm 0.827 \mathrm{~mm}$ and $5.244 \pm 0.950 \mathrm{~mm}$ on left side and this difference was not statistically significant. According to previous studies, average width of FO in adult skulls was 3.7 $\mathrm{mm}$ (14), whereas it was $3.21 \pm 0.02 \mathrm{~mm}$ and $3.29 \pm 0.85 \mathrm{~mm}$ on right side and left sides (3). Also, the average width was 3.4 $\mathrm{mm}$ on right side and $3.8 \mathrm{~mm}$ on left side according to a study conducted by fluoroscopically-assisted laser targeting of FO in New York (13).

The mean area of FO calculated in the present work was $30.808 \pm 7.545 \mathrm{~mm}^{2}\left(54.95-14.13 \mathrm{~mm}^{2}\right)$ and $31.310 \pm 8.262$ $\mathrm{mm}^{2}$ (53.38 $-14.13 \mathrm{~mm}^{2}$ ) on the right and left sides and in an previous study, the combined area of FO ranged from 25.99 $67.40 \mathrm{~mm}^{2}$ in adult male skulls to $19.58-67.40 \mathrm{~mm}^{2}$ in case of female skulls (5).

In the present study, with regard to variations in the shape of FO, the oval shape was most common (56.70\%), followed by almond and round shapes, similar to the studies conducted in the past $(5,22)$. Also various bony outgrowths of the FO like spine on the margin of $\mathrm{FO}$, tubercle protruding from its margin and bony lamina extending from lateral pterygoid plate dividing the foramen into two incomplete compartments, etc. were noticed in the present study.

In the sphenoid bone, first ossification centre appears in the great wings of sphenoid bone and the earliest perfect ringshaped formation of the FO is observed in the 7th foetal month and the latest in 3 years after birth (22) and the ossification takes place around the large trunk of mandibular nerve. The appearance of the various bony outgrowths of the FO like Spine, spur, tubercle, bony plate etc indicate bony overgrowth during its developmental process, between its first appearance and perfect ring formation and also the various inconstant patterns of grooves and foramina in the vicinity of the FO can be interpreted as arising from the interplay of various parts of membrane bone and the emissary venous plexus from the middle meningeal veins to the pterygoid plexus (10).

\section{CONCLUSION}

So from the present study we found $9.14 \%$ (15 in 164 sides) of the foramina ovale may be variant due to developmental reasons either have a spine, tubercle bony plate or a bridge like bony spur signifying the over-ossification during developmental process, which may seriously hamper diagnostic and therapeutic procedures through the FO. Analyzing the length, width and area of FO on both the sides, there was no statistical differences and the values were comparable with the studies done in the past. Also, this study has clinical and anatomical significance for the medical practitioners in cases of trigeminal neuralgia and in diagnostic detection of tumors and abnormal bony outgrowths that may lead to ischemia, necrosis etc.

\section{ACKNOWLEDGEMENTS}

The authors are very thankful to Mr. M.S. Kotian, Department of community medicine, Kasturba Medical College, Mangalore, for his valuable help in the statistical analysis of the data and are also grateful to the departments of Anatomy, Kasturba Medical College, Mangalore \& Manipal, Manipal University, for providing the required bone specimens. 


\section{REFERENCES}

1. Arun SK: Some observations of the foramina ovale and spinosum of human sphenoid bone. J Anat Soc India 55(1): 100-101, 2006

2. Barakos JA, Dillon WP: Lesions of the foramen ovale: CT-guided fine-needle aspiration. Radiology 182: 573-575, 1992

3. Biswabina R, Nirupma G, Supriya G: Anatomic variations of foramen ovale. Kathmandu University Medical Journal 3(1): 64-68, 2005

4. Błaszczyk B, Kaszuba A, Kochanowski J: Atypical foramina of the base of the skull. Folia Morphol 93: 201-209, 1980

5. Chimmalgi M, Kulkarni Y, Sant SM: Sexing of skull by new metrical parameters in west India. J Anat Soc India 56(1): 28-32, 2007

6. Dresel SH, Mackey JK, Lufkin RB: Meckel cave lesions: Percutaneous fine needle-aspiration biopsy cytology. Radiology 179: 579-582, 1991

7. Gerber AM: Improved visualization of the foramen ovale for percutaneous approaches to the gasserian ganglion: Technical note. J Neurosurg 80: 156-159, 1994

8. Gozil R, Keskil S, Calguner E, Tunc E, Kadioglu D, Sevim A, Onal, B, Baykaner K: Neurocranial morphology as determined by asymmetries of the skull base. J Anat 189: 673-675, 1996

9. Gusmão S, Oliveira M, Tazinaffo U, Honey CR: Percutaneous trigeminal nerve radiofrequency rhizotomy guided by computerized tomography fluoroscopy: Technical note. J Neurosurg 99: 785-786, 2003

10. James TM, Presley R, Steel FL: The foramen ovale and sphenoidal angle in man. Anat Embryol 160: 93-104, 1980

11. Kapur E, Dilberović F, Redzepagić S, Berhamović E: Variation in the lateral plate of the pterygoid process and the lateral subzygomatic approach to the mandibular nerve. Med Arh 54: $133-137,2000$
12. Kuta AJ, Laine FJ: Imaging the sphenoid bone and basiocciput: Anatomic considerations. Semin Ultrasound CT MR 14: 146-159, 1993

13. Landl MK, Walter Grand: Trigeminal Neuralgia: Fluoroscopically -Assisted Laser Targeting of the Foramen Ovale: Technical Note. Minrad International, 2005

14. Lang J: Clinical Anatomy of the Head, Neurocranium, Orbit and Craniocervical Region, Springer-Verlag, Berlin 1883

15. Lang J, Maier R, Schafhauser O: Postnatal enlargement of the foramina rotundum, ovale et spinosum and their topographical changes. Anatomischer Anzeiger 156 (5): 351-387, 1984

16. Osunwoke EA, Mbadugha CC, Orish CN, Oghenemavwe EL, Ukah CJ: A morphometric study of foramen ovale and foramen spinosum of the human sphenoid bone in the southern Nigerian population. J Appl Biosci 26: 1631-1635, 2010

17. Reymond J, Charuta A, Wysocki J: The morphology and morphometry of the foramina of the greater wing of the human sphenoid bone. Folia Morphologica 64(3): 188-193, 2005

18. Sindou M, Chavez JM, Saint PG: Percutaneous biopsy of cavernous sinus tumours through the foramen ovale. Neurosurgery 40: 106-111, 1997

19. Soames RW: Gray's Anatomy of the Human Body, 38th ed. London: Churchill Livingstone, 1995: 425-736

20. Standring S: The Anatomical Basis of Clinical Practice, Gray's Anatomy, 39th edit. Elsevier Limited, 2006:460-462

21. Wieser HG, Siegel AM: Analysis of foramen ovale electroderecorded seizures and correlation with outcome following amygdalohippocampectomy. Epilepsia 32: 838-850, 1991

22. Yanagi S: Developmental studies on the foramen rotundum, foramen ovale and foramen spinosum of the human sphenoid bone. The Hokkaido Journal of Medical Science 62(3): 485-496, 1987 